\title{
Application and Exploration of Overall Risk Management in Construction Enterprises
}

\author{
Hongyun Tian* \\ China First Metallurgical Group Co., Ltd., China \\ *Corresponding author: Hongyun Tian, 296106509@qq.com
}

\begin{abstract}
This paper mainly starts from the perspectives of management and economics, combined with the characteristics of the construction industry, conducts qualitative and quantitative analysis of the risks involved, studies various factors that cause construction enterprise risks from multiple angles, and uses scientific and effective methods to identify and evaluate risks, as well as determine the risk level. Through the overall risk management response strategies and empirical research of construction enterprises, this paper analyzes the general theory and main avoidance strategies of risk response of construction enterprises, and lays the foundation for follow-up risk management response in the form of cases through the implementation of technical route and innovation points.
\end{abstract}

Keywords: Overall risk management; Construction enterprises; Empirical risk control and countermeasures

Publication date: November 2021; Online publication: November 30, 2021

\section{Introduction}

\subsection{Research background and significance}

According to the statistics of the American Loss Control Association, enterprises without risk management are more likely to go bankrupt after a huge disaster. Zhuopu Wang believes that the construction project is a systematic project, which generally has different subsystems, and each subsystem will have some procedural standards and specifications. These standards and specifications often have been tested in practice for a long time and are relatively mature ${ }^{[1]}$. The realization of overall risk management is not only the need of the country, but also the need of the development of their own enterprises.

\subsubsection{Requirements of national policies}

For China's construction industry, it has long relied on the active fiscal policy for many years and the rapid growth of fixed asset investment scale, and has taken the road of denotative and extensive development. Many enterprises have a debt ratio of more than $80 \%$, and the profits of construction enterprises are getting thinner and thinner and the risks are getting bigger and bigger. In 2006, SASAC issued the Guidelines on Overall Risk Management for Central Enterprises, which is divided into 10 chapters and 70 articles, and puts forward clear requirements for overall risk management of central enterprises. Therefore, the implementation of the sustainable development strategy of overall risk management in the construction industry is the only way for central enterprises to adapt to the competition of economic globalization and narrow the management gap with large international companies.

\subsubsection{Requirements for the development of the construction industry}

During the Eleventh Five Year Plan period, the number of domestic construction enterprises reached 68283, the output value profit margin of construction enterprises always hovered between $1 \% \sim 2 \%$, the 
homogenization competition was becoming increasingly fierce, the profits of construction enterprises were seriously squeezed, and they had entered a "low profit era" and "no profit era." As of September 2010, China's foreign contracted projects had accumulated an operating revenue of US $\$ 400$ billion, and the scale of participating in international competition has increased, but the quality is not high, the development mode is extensive, the profitability is weak, and the business structure needs to be further optimized. By implementing the sustainable development strategy of overall risk management, it is necessary to correctly identify and evaluate all risks faced by the enterprise, provide the basic basis for the enterprise's strategic decision-making, and make the enterprise develop healthily.

\subsection{Review of research status at home and abroad}

Since CAS (Casualty Actuarial Society) proposed Enterprise Risk Management or Enterprise wide Risk Management (ERM) in 2001, this theory has developed rapidly in western countries. Its core idea is: Risk comes from many aspects, and it is often not a single aspect but a combination of multiple risks that can ultimately have a risk effect on the enterprise. Therefore, only comprehensive risk management is the most effective way.

The events of Enron and WorldCom in 2001 made risk management get the attention and thinking of all sectors of society. The National Anti-Fraud Financial Reporting Council Committee of Sponsoring Organization (COSO) launched Enterprise Risk Management -- Integrated Framework in 2004, which focused more on enterprise risk management, and gradually become the national and world standard.

In China, the practice and theoretical research of risk management can be traced back to the 1930s. After decades of development, the current risk management research is becoming more and more mature. Especially in the aspect of engineering construction project risk assessment methods and technologies, many risk assessment methods have been developed, such as expert scoring method, fuzzy mathematics method, probability statistics method, decision tree method, sensitivity analysis, Monte Carlo simulation, RBI method, analytic hierarchy process, CIM model and impact diagram ${ }^{[2,3]}$.

In the 1980s, the risk management theory was introduced into China by the Kailing Duan, a Chinese living in the United States. Subsequently, a large number of scholars have invested in the research of risk management theory, of which the typical representative is Zhongwei Guo. After systematic research and summary, he published Risk Analysis and Decision Making in 1987, which is the first work on risk management in China and has milestone significance.

In general, the lack of risk management in construction enterprises has attracted the attention of scholars at home and abroad. However, the relevant theoretical and practical research is just beginning, and the systematically theoretical system is not perfect. From the research results, we have done a lot of research on contract risk and investment risk, but mainly introduce the theory of risk management abroad, and the theory of local innovation is relatively small. VaR (Value at Risk) model; TRM (Total Risk Management) theory; ERM (Enterprise Risk Management) theory; GRM (Global Risk management). As VaR, TRM and GRM are generally only used in the financial sector, while ERM is applicable to most enterprises and has attracted great attention, central enterprises and listed companies must use the Enterprise Risk Management framework. As a pillar industry of the national economy, the construction industry has gradually extended to the high-end of the value chain with the transformation and development of general construction contracting to general engineering contracting. Design business drives the rapid development of construction business, construction general contracting (EPC), project management general contracting (PMC), construction engineering management (CM), construction-operation-transfer (BOT) and other businesses continue to expand, which brings many risks such as market supply and demand change, capital advance, default, exchange rate fluctuation, project delay, quality and safety accidents, joint liability of project subcontracting and personnel appointment. Enterprises have more and more clear concept of risk 
control, and the demand is more and more urgent. It is necessary to strengthen the risk management ability of construction enterprises.

\subsection{Research objectives and contents of this paper}

The research goal of this paper is to comprehensively summarize and refine the risk management theory of construction enterprises, deeply analyze various potential risks faced by construction enterprises, put forward risk identification methods, effectively evaluate the risks of construction enterprises, and finally provide guidance and help for overall risk management of construction enterprises. The research methods mainly include literature method, expert investigation method, case analysis and empirical research method, follow the research ideas from theory to demonstration, and gradually analyze the risk identification and risk control methods of construction enterprises. The specific research route is shown in Figure 1.

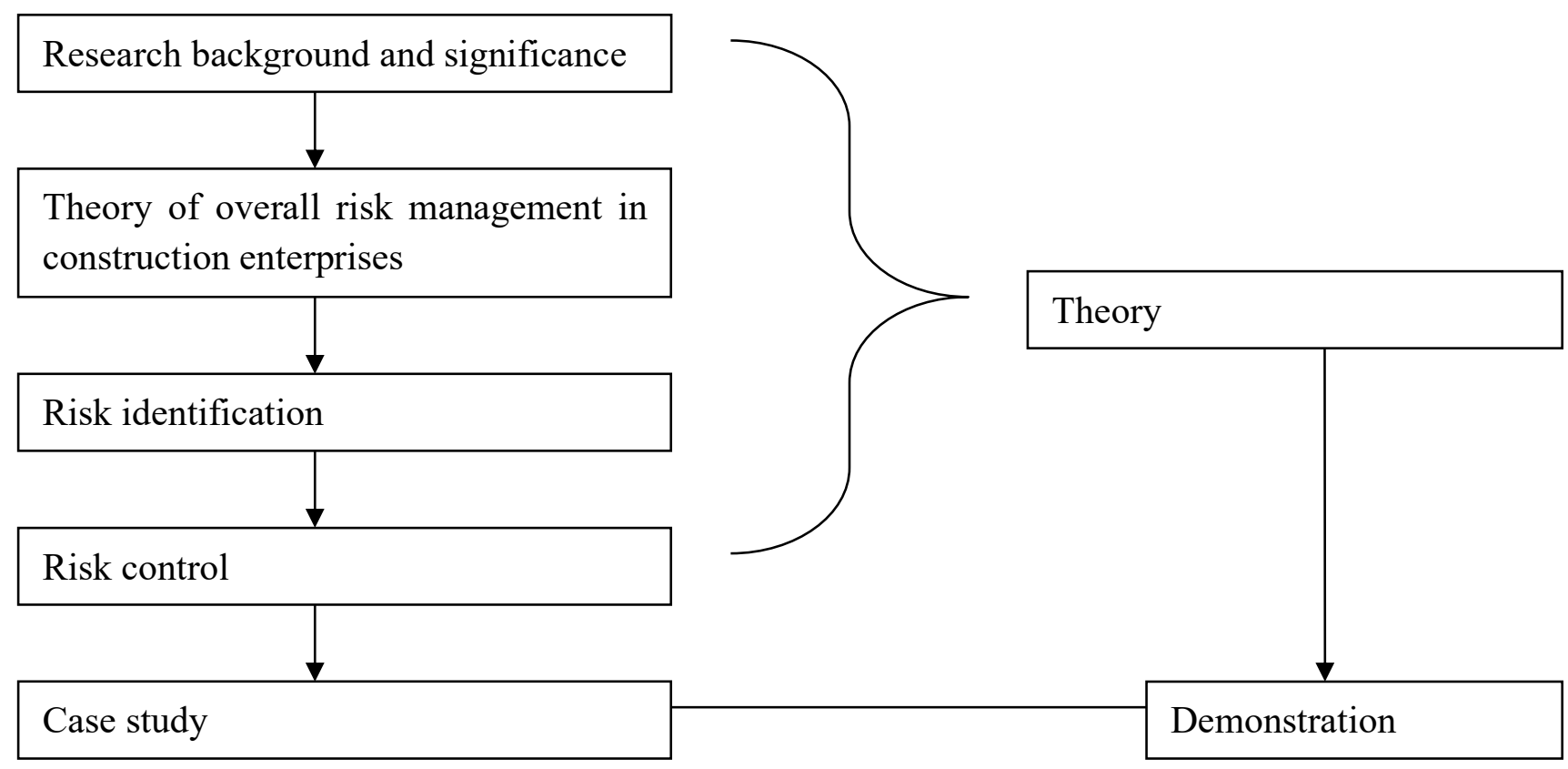

Figure 1. Technical route of research in this paper

\section{Theoretical basis of overall risk management in construction enterprises}

\subsection{Main types of construction enterprise risks}

With the development of risk theory, especially for the needs of risk management, people have conducted in-depth research on the types and characteristics of risk, and summarized the types of risk mainly from the perspective of risk nature, risk source, risk subject preference, risk object and technology. See Table 1. For details.

The development of technology is also an important factor to promote the development and progress of construction enterprises. The common technical factors include survey and design, drawing design, construction technology and so on. There still are many specific events causing technical risks, as shown in Table 2. 
Table 1. Classification of general risks

\begin{tabular}{|c|c|c|}
\hline $\begin{array}{c}\text { Classification } \\
\text { method or basis }\end{array}$ & Risk type & Characteristic \\
\hline \multirow{2}{*}{$\begin{array}{l}\text { Classification by risk } \\
\text { nature }\end{array}$} & Pure risk & It will only bring damage, not opportunities or benefits \\
\hline & Speculative risk & $\begin{array}{l}\text { It may bring opportunities and gain benefits, but it may } \\
\text { imply threats and cause losses }\end{array}$ \\
\hline \multirow[b]{2}{*}{$\begin{array}{l}\text { Classification by risk } \\
\text { source }\end{array}$} & Natural risk & Property damage or casualties due to natural forces \\
\hline & Human risk & $\begin{array}{l}\text { The risk caused by human activities is man-made risk, } \\
\text { which can be divided into behavioral risk, economic risk, } \\
\text { technical risk, political risk, organizational risk and so on. }\end{array}$ \\
\hline \multirow{2}{*}{$\begin{array}{c}\text { Classification by risk } \\
\text { event } \\
\text { bearing capacity }\end{array}$} & Acceptable risk & Risk limited to a certain degree \\
\hline & Unacceptable risk & $\begin{array}{l}\text { The risk of exceeding the maximum loss that can be borne } \\
\text { or huge deviation from the target }\end{array}$ \\
\hline \multirow[b]{3}{*}{$\begin{array}{c}\text { Classification by risk } \\
\text { object }\end{array}$} & Property risk & Risk of loss, damage or depreciation of property \\
\hline & Personal risk & Risks caused by disease, disability and death \\
\hline & Liability risk & $\begin{array}{l}\text { The behavior of legal person or natural person violates the } \\
\text { provisions of law, contract or morality, causing property } \\
\text { loss or personal injury to others }\end{array}$ \\
\hline \multirow{2}{*}{$\begin{array}{l}\text { Impact of technical } \\
\text { factors on risks } \\
\text { Impact classification }\end{array}$} & Technical risk & The risks caused by technical reasons are man-made risks \\
\hline & $\begin{array}{l}\text { Non-technical } \\
\text { risk }\end{array}$ & Risks due to non-technical reasons \\
\hline
\end{tabular}

Table 2. Examples of technical risk events

Risk factor

Feasibility study

Design

Construction

\section{Typical risk events}

The basic data is incomplete and unreliable; The analysis model is unreasonable; Prediction results is inaccurate, etc

Design content is incomplete; Design wxits flaws, errors and omissions; Selection of specifications and standards is improper; Selection of safety factor is unreasonable; Address data is insufficient or unreliable; The possibility of construction is not considered.

Construction technology is backward; Construction technology and scheme is unreasonable, and construction safety measures is improper; Application of new technologies and methods fails; The actual situation of the construction site is not considered.

The process design does not meet the advanced indicators and reasonable process flow department, as well as the project quality inspection and acceptance do not meet the specified requirements

The non-technical risks of construction enterprises are mainly various uncertainties and possible losses caused by management factors in the process of construction. Such as fund management, cost control, schedule management, construction organization management, etc. Common non-technical risk events are 
shown in Table 3.

Table 3. Examples of non-technical risk events

\begin{tabular}{ll}
\hline \multicolumn{1}{c}{ Risk factor } & \multicolumn{1}{c}{ Typical risk events } \\
\hline $\begin{array}{l}\text { Project } \\
\text { organization } \\
\text { management }\end{array}$ & $\begin{array}{l}\text { Lack of project management ability; Improper organization, frequent replacement } \\
\text { of personnel in key positions, inappropriate project objectives and poor control; } \\
\text { Improper project planning or arrangement; Lack of project management and } \\
\text { cooperation. }\end{array}$ \\
& $\begin{array}{l}\text { The construction period is delayed due to poor management; Schedule adjustment } \\
\text { rules is inappropriate; Lack of labor or low labor productivity, and the supply of } \\
\text { materials cannot keep up; The supply of design drawings lags behind; Site } \\
\text { conditions is unforeseen; The construction site is too small or the traffic route does } \\
\text { not meet the requirements. } \\
\text { Construction delay; Inappropriate engineering changes; Inappropriate engineering } \\
\text { payments; Contractor's claim; Low budget; Lack of management experience; } \\
\text { Inappropriate procurement strategies; Changes in external conditions of the project. }\end{array}$ \\
& Construction disturbance; Shortage of funds; Insolvency \\
\hline
\end{tabular}

From the perspective of objectives, the risks of construction enterprises mainly include construction period risk, construction quality risk and investment cost risk.

\subsection{Overall risk management of construction enterprises}

The Guidelines on Overall Risk Management for Central Enterprises ${ }^{[4]}$ defines overall risk management, comprehensively examines the meaning and characteristics of risk, especially the essence of risk management. The author believes that overall risk management of construction enterprises is to comprehensively identify the possible risks in each link based on the comprehensive analysis of the environment of construction enterprises and around the goal. Through scientific evaluation, a comprehensive construction enterprise risk management system is established. Its essence is risk identification and control. The core contents include: risk identification, estimation, evaluation and control of construction enterprises. See Figure 2.

In terms of time, the risk of construction enterprises runs through the whole process of construction projects. From the perspective of management objects, there are many contents. The objects and focus should focus on the projects with new processes, large investment scale, large impact (political, economic and social), strict administrative and financial requirements and special contracts. The following links are the key links with various risks and need to be paid high attention, as shown in Figure 3. The supervision of these links is of great significance to the implementation of comprehensive risk management of construction enterprises. 


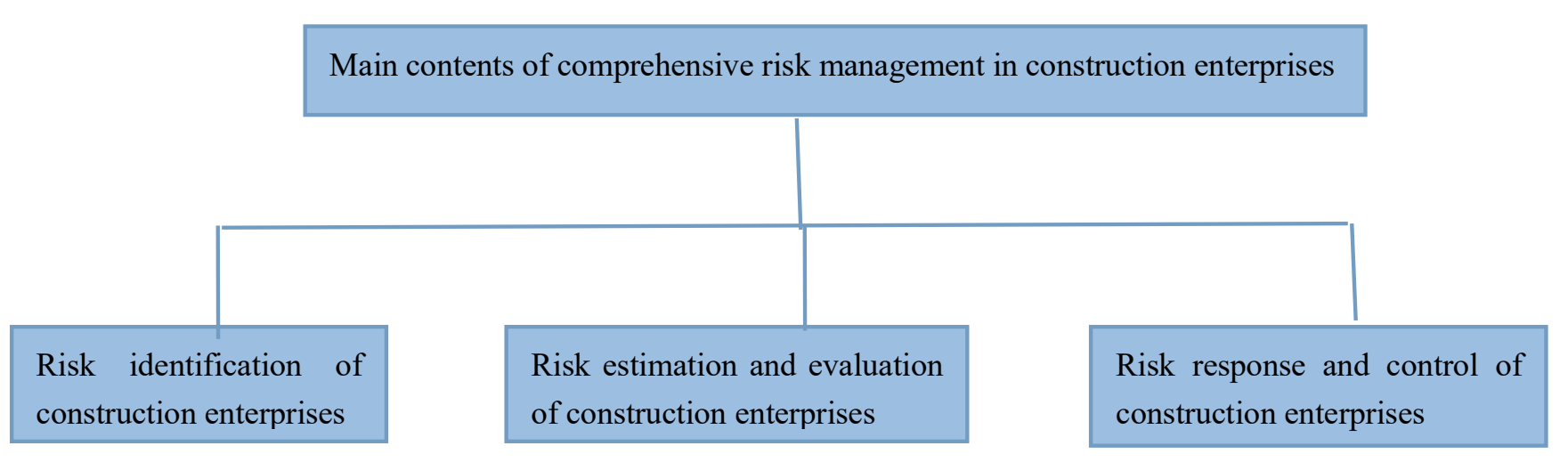

Figure 2. The main content of the overall risk management of construction enterprises

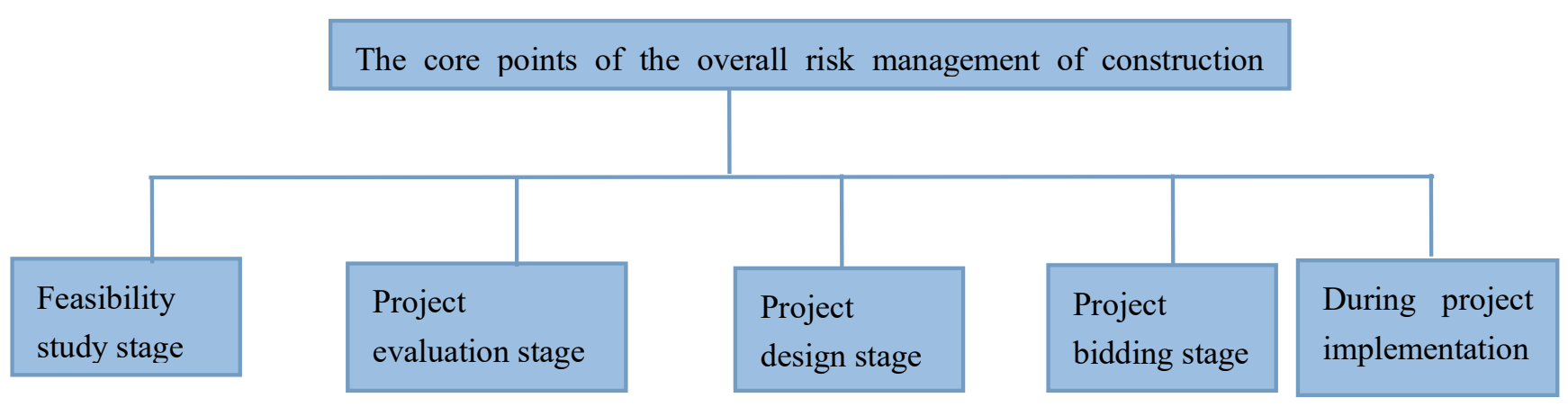

Figure 3. The core points of the overall risk management of construction enterprises

\subsection{Risk identification, estimation and evaluation of construction enterprises}

Construction enterprises face three main objectives: quality, schedule and cost. The key to realizing comprehensive risk theory lies in risk identification. The main methods include: historical experience analysis method, expert interview method, analysis tool method, analytic hierarchy process, checklist method, decomposition analysis method and graphic method. Risk identification mainly includes four links, and the specific process is shown in Figure 4.

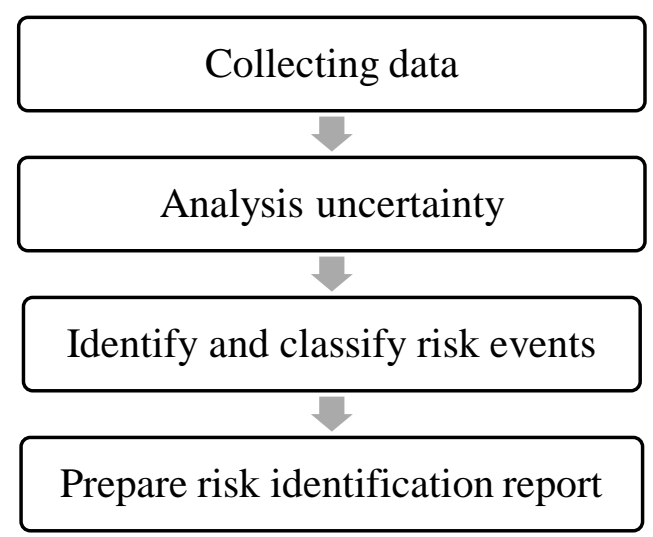

Figure 4. General process of risk identification

Construction enterprise risk estimation is to analyze the probability, time, possible loss and impact of risk in the construction process, and estimate and measure it through scientific methods. Its main function is to serve risk management decision-making. Generally, it includes several stages such as data collection, 
model establishment and risk evaluation ${ }^{[5]}$, as shown in Figure 5.

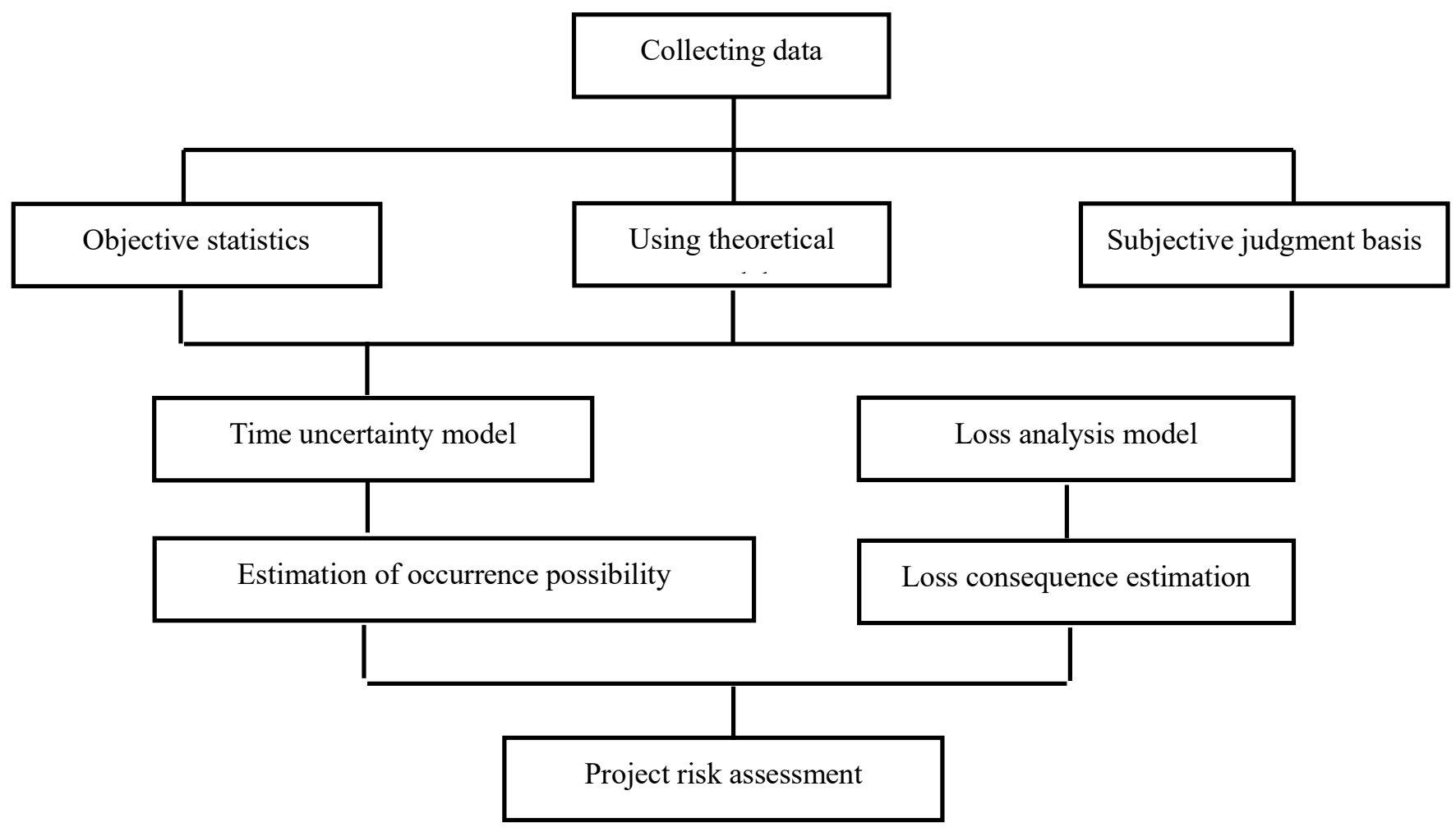

Figure 5. General process of construction enterprise risk estimation

Generally, the risk evaluation can be completed according to the following three steps ${ }^{[6]}$ :

(1) Different risk evaluation criteria are determined according to the risk preference and affordability of construction enterprises.

(2) Determine the risk level of the risk of the construction enterprise that has occurred, and estimate the loss of risk consequences through the measurement of the risk level.

(3) Evaluate and compare different risk events and risk losses, so as to provide basis for what risk response measures to take.

\section{Countermeasures and empirical research on comprehensive risk management of construction enterprises}

3.1. Risk response strategy of construction enterprises

In the face of various risks, the commonly used response strategies include risk avoidance, risk mitigation, risk transfer, risk retention and risk utilization. At the same time, the combination of the above strategies will also be adopted. In fact, due to the different risk preference and risk tolerance of construction enterprises, the risk avoidance strategies adopted in practical activities are also different. In order to better guide construction enterprises to resolve various risks, Shengqiang Lei, in his book International Engineering Risk Management and Insurance, listed risk management strategies commonly used by construction enterprises and their countermeasures in detail ${ }^{[7]}$.

\subsection{Case study of overall risk management of construction enterprises}

Taking the comprehensive risk management implemented by Industrial Furnace Engineering Company of China First Metallurgical Group Co., Ltd. in the process of transformation and development as an example, 
according to the basic idea of comprehensive risk management of "overall planning, highlighting key points, step-by-step promotion and integrated operation," combined with the development status of main business segments, this paper defines the main processes and operation methods of risk management, The construction of internal control system for basic comprehensive risk management has been completed (Figure 6). The achievement won the second prize of the innovation achievement of modern management of national construction enterprises in 2012.

Specifically, the risk of an enterprise comes from many aspects. What ultimately affects the enterprise is not a certain risk, but the result of the joint action of all risks. Therefore, only the risk management from the overall perspective of the enterprise is the most effective. "Sustainable development strategy of implementing comprehensive risk management" is a management concept suitable for its own development summarized and refined by industrial furnace engineering company of China First Metallurgical Corporation on the basis of absorbing and learning from the essence of advanced management at home and abroad. Its connotation is to link risk preference with enterprise strategy; Ensure that the risk management strategy is consistent with the development strategy of the enterprise; Provide tools for identifying and assessing risks to facilitate the identification and assessment of risks faced by the organization; Provide tools for scientific classification of risks, use the concept of risk optimization, and explore risk issues based on portfolio view; Integrate enterprise risk management with basic business activities to avoid additional costs. And it was put into management practice in January 2012. Through the implementation of control environment, risk assessment, control activities, information and communication, internal supervision and other activities, the construction of the internal control system of basic comprehensive risk management has been completed, and the sustainable development of the enterprise has been promoted. The main methods are:

3.2.1. Widely collected the internal and external initial information related to the company's risk, and formulate the enterprise development strategy suitable for the sustainable development of comprehensive risk management

According to the basic principle of "risk concentration and hierarchical management," and based on the existing organizational system and management structure, the group has established a comprehensive risk management organization system composed of the company's office (including the legal and discipline inspection commission), finance and asset management department, operation management department, audit and supervision department, human resources department, engineering department and other functional departments. Collect information through network, books, periodicals, newspapers and association exchanges, and analyze the current situation and development trend of the company's field. Combined with the company's existing technical equipment level, personnel skills and comprehensive resource holdings, the development strategies of the three main business sectors are determined to form an industrial development pattern with complementary industries, reasonable structure, and harmonious and unified operation quality, profitability and anti-risk ability. According to the strategic development objectives formulated by the enterprise, as well as the supporting strategic objectives, business objectives, reporting objectives and compliance objectives, the general objectives and annual objectives of ERM system construction are formulated.

\subsubsection{It has established an internal control system with the organic combination of corporate governance, risk management and internal audit}

Reorganized and defined the business process and business level process, reasonably adjusted the organization, allocated resources, reengineered the management process, reformed the organization of the original departments and entities, redefined the staffing and posts, established an independent audit and 
supervision department, and transferred the construction function of comprehensive risk management system to the company's Office (including corporate planning function). As the third line of defense of risk management, the audit and supervision department is responsible for supervision, inspection and evaluation. According to various documents and new businesses formed in the enterprise business in the past, a total of 48 business processes are proposed, standard flow charts are drawn and standardized with systems to prevent cross and duplication of departments and clear interface management. According to the Basic Norms for Internal Control of Enterprises, the Manual for Internal Control of Corporate Risks was prepared (including risk summary table, process map, job list with incompatible responsibilities and risk control matrix), and defined the internal control system architecture. The management is responsible for organizing and leading the daily operation of the internal control system of risks. The audit department shall specifically organize and coordinate the establishment, implementation and daily work of the risk internal control system, as well as supervise and inspect the effectiveness of internal control. It has promoted the standardization and normalization of the construction of risk internal control system. At the same time, the relevant systems involved in the company's business processes have been supplemented and revised, and the company's system platform has been built with the combination certification of quality, environment, occupational health and safety management system as the framework, which has solved the problems of fuzzy process, unclear interface, unclear responsibility and so on in the enterprise's operation and management, especially in the project cost control, so that the connotation of standardized management of the company can be effectively extended(Figure 7 ).

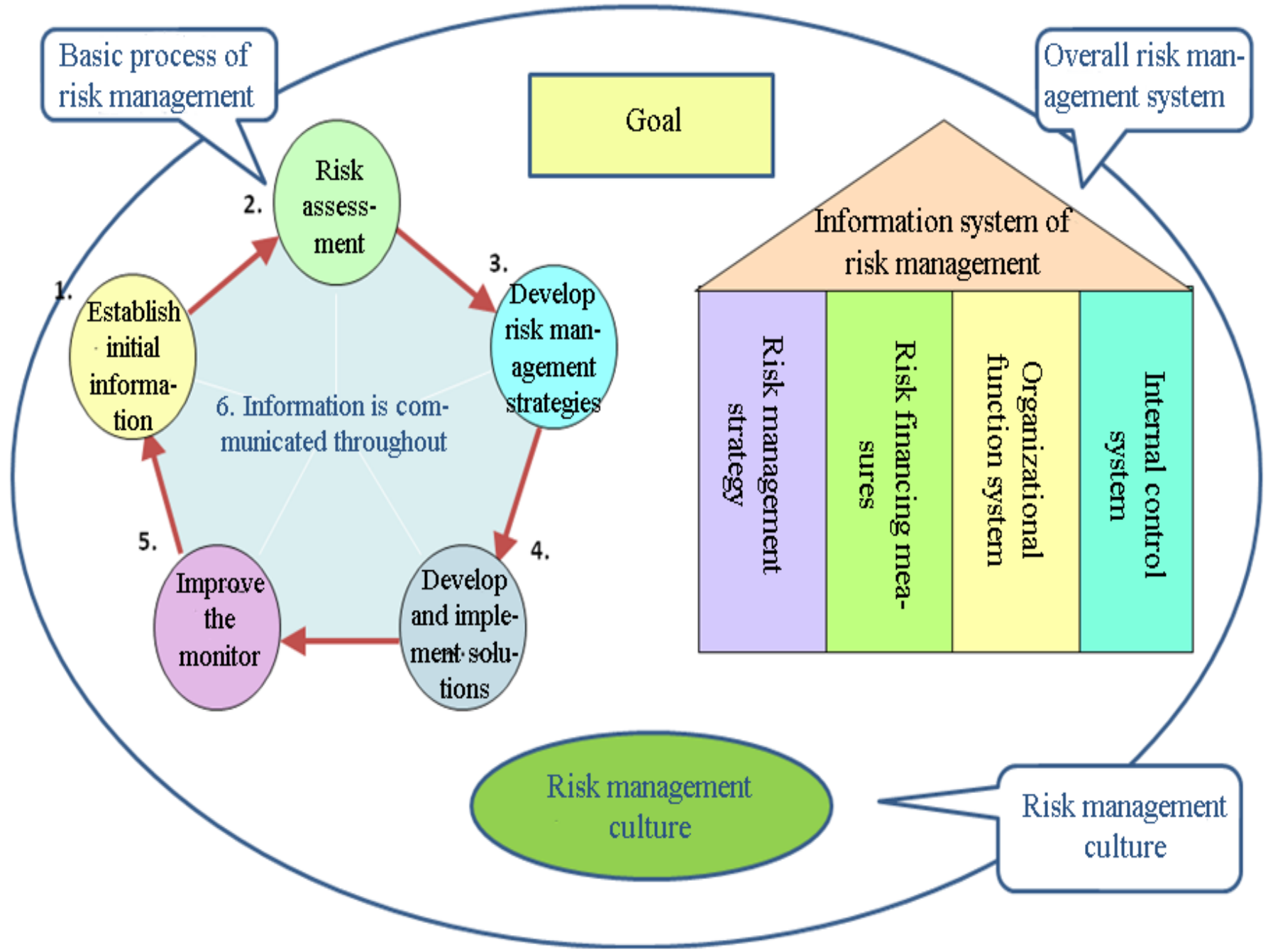

Figure 6. Risk management system of industrial furnace company 


Corporate
governance:
- The top administrator
shall timely understand
the nature of the
company's major risks
and their impact on
strategic objectives
- Supervise the
management's activities
and ability to manage
risks
$\bullet \quad$ Supervise the work
scope and quality of risk

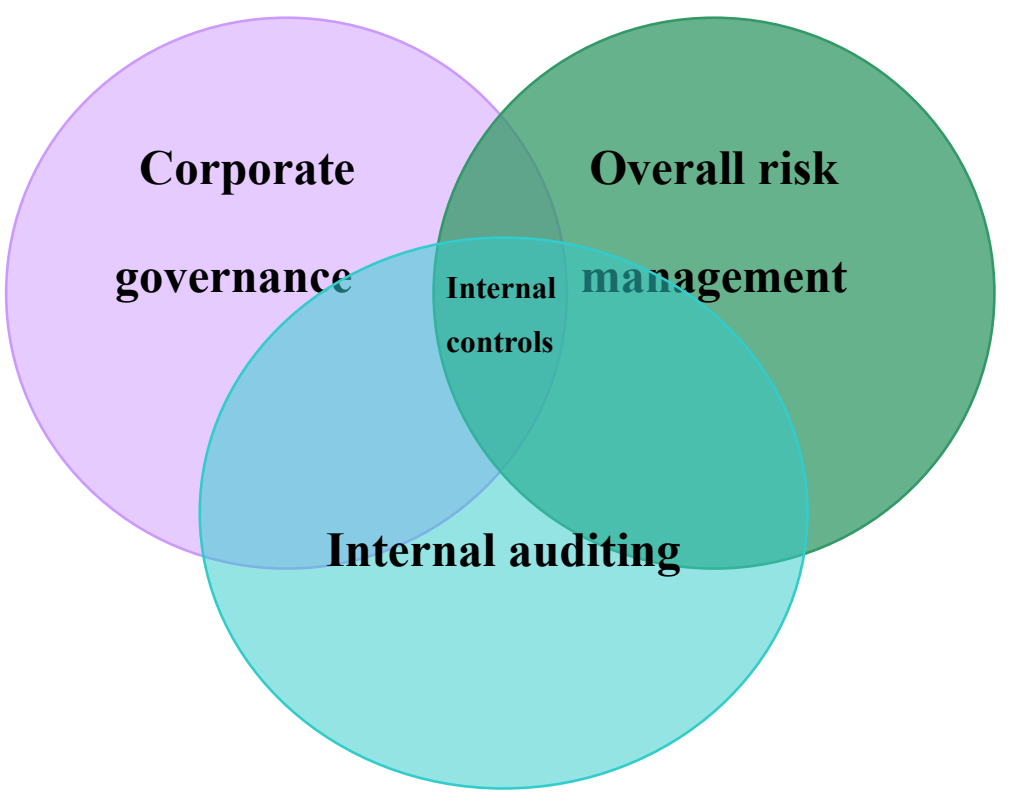

Overall

risk management:

- Help management identify and assess risks

- Develop correct risk management strategies

- Regularly provide risk status reports to top administrator and management to monitor risks

- Associate risks with the internal control system to provide a basis for internal audit

Internal auditing:

- Develop an internal audit plan based on the results of the risk assessment

- Audit the design effectiveness and implementation effectiveness of internal control system for major risks

- Provide management suggestions to the company's management and reduce

Figure 7. Risk management oriented internal control system

\subsubsection{Actively carry out comprehensive risk assessment of basic process management and formulate scientific and objective risk treatment strategy combination}

In the process of operation, enterprises will face various risks from external business environment, internal operation, management, finance, credit and transaction, forming the risk universe of enterprises. According to the diagnosis of the possibility and impact of various risks, an enterprise's risk map can be formed.

Firstly, the 48 project management departments under construction issued a notice to collect risk cases of projects under construction, collected 76 risk cases, and put forward the countermeasures to be taken to control and resolve risks. At the same time, in combination with the annual internal control inspection, project patrol inspection, system internal audit, small treasury inspection and other work, understand the cognition of the project management department on risk and risk management, the uncertain factors and urgent problems faced by various functional departments in the business management process, and comprehensively grasp the basic risk information.

Secondly, functional departments were organized to fill in professional risk event cases on the front, 69 risk identification items and 22 risk cases were collected, 10 major risks and internal control defects were collected, and improvement measures and countermeasures were put forward, involving coke oven construction, heating furnace construction and dry quenching system engineering, among which, the major internal risk inspection items involve 5 first-level risk items, including strategy implementation risk, project decision-making risk, business collaboration risk, project implementation risk and contract management risk, and 38 minor items. Risk identification and risk case database are preliminarily collected and built. 
Through the analysis of the existing operation strength, main financial data and operation indicators, the risk assessment standards at the company level are determined. The risk is assessed from two dimensions: the possibility of risk occurrence and the degree of impact. The possibility of risk occurrence is divided into five levels: very low, low, medium, high and very high (Figure 8). The degree of impact of risk is divided into five levels: slight, small, medium, serious and very serious. According to the impact areas of main risks, it is further subdivided into financial, safety, health and environmental protection target and operation, as well as the company's reputation. Through the collection of risk cases, it is found that some management processes of the functional departments are not implemented in place, the comprehensive unit price of the project management department is low, the subcontracting funds exceed the contract payment, the market material price rises, the settlement of completed projects lags behind, the funds collection is difficult, and the delivery file handover is not complete; Conduct a comprehensive and in-depth analysis on the collected risk distribution, risk characteristics, risk causes, risk impact and existing control measures, put forward directional suggestions on major risk management, prepare for the response to major risks, and formulate risk coordinates.

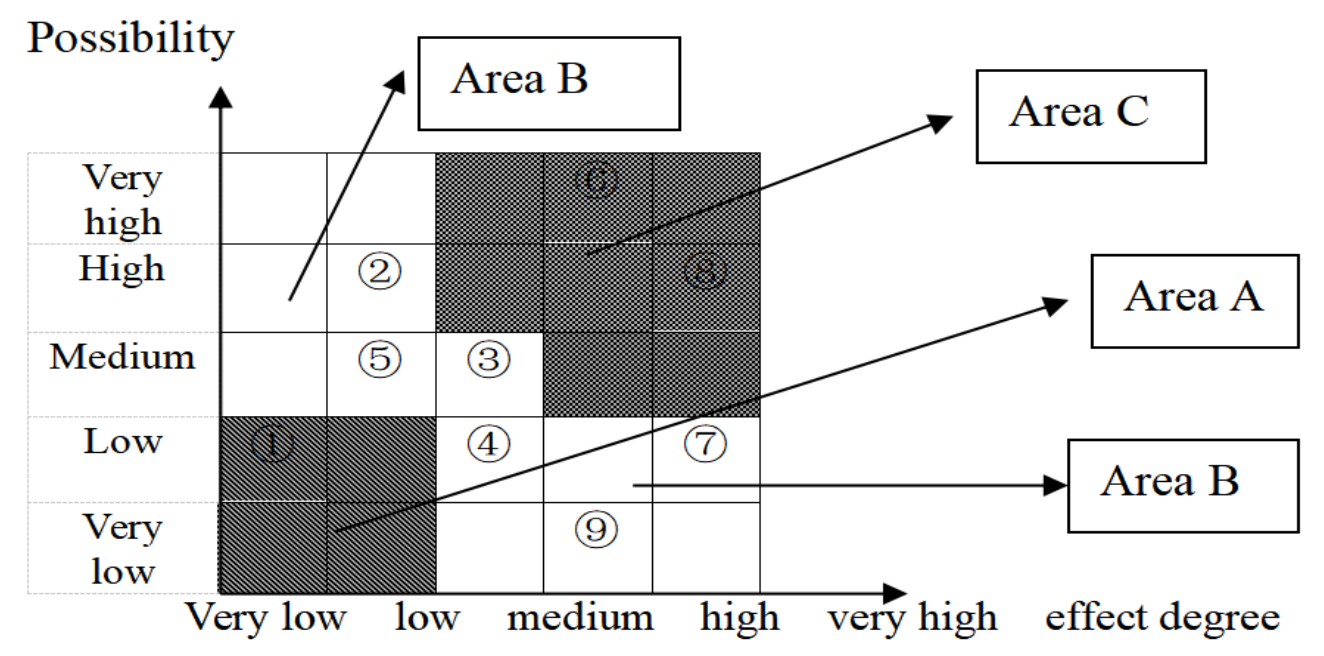

Figure 8. Risk coordinates

As shown in Figure 8, the chart is divided into three areas A, B and C. The risk control team decides to assume all risks in area A and will not add control measures; Strictly control various risks in area B and specially supplement and formulate various control measures; Ensure to avoid and transfer various risks in area $\mathrm{C}$, and give priority to the implementation of various preventive measures.

Establish and improve the risk management evaluation index system, strengthen the supervision function of risk management evaluation, deeply integrate with daily operation management, and determine the risk evaluation index system at the company level and business level (Figure 9).

\subsubsection{Implementation effect of sustainable development strategy of basic overall risk management}

The company's capital management and control, marketing and other major business activities have been strengthened. The systems of business performance assessment, budget management, property right management and asset management have been continuously improved. Under the platform of modern enterprise system, the enterprise strategy transfer has been smoothly completed, and the core competitiveness of the enterprise has been fully reflected in the reform of dynamic adjustment system. The output value and profit are increasing year by year. The company has been approved as the "furnace building technology research and direction base" of China Metallurgical Group Corporation, and the "7.63m coke oven masonry method" has won the national construction method. "New energy-saving and environment-friendly coking system engineering construction technology" was listed as a national key 
construction new technology research and direction project by the ministry of finance, and was allocated 1 million yuan by the ministry of finance. Coking System Engineering of Section A of Coking System Engineering of New District of Handan Iron and Steel Co., LTD. won the first prize of the third national excellent project management achievement of construction engineering. Please see Table 4. for details.

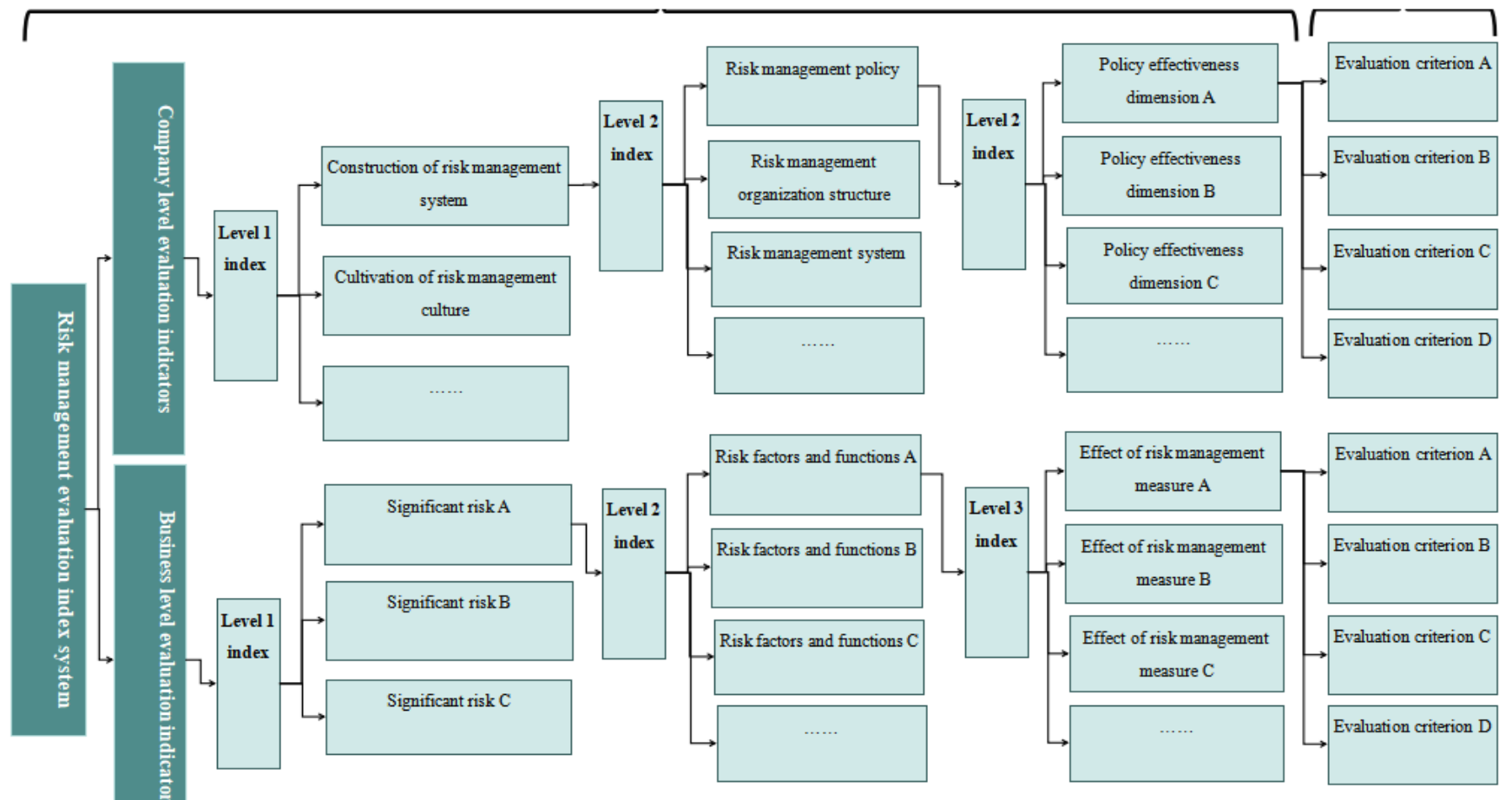

Figure 9. Risk management evaluation index system

Table 4. Comparison of technical innovation indicators before and after the implementation of achievements

\begin{tabular}{|l|c|c|}
\hline Indicator name & $\begin{array}{l}\text { 2010, the year before } \\
\text { the implementation of } \\
\text { the results }\end{array}$ & $\begin{array}{l}\text { 2011 to 2012, the year when the } \\
\text { implementation of the results } \\
\text { accumulates }\end{array}$ \\
\hline Number of patent applications & 17 & 131 \\
\hline $\begin{array}{l}\text { Number of provincial and ministerial } \\
\text { achievements }\end{array}$ & 2 & 6 \\
\hline $\begin{array}{l}\text { Number of provincial and ministerial } \\
\text { construction method }\end{array}$ & 0 & 4 \\
\hline $\begin{array}{l}\text { Number of editor-in-chief and } \\
\text { participating editors of standards and } \\
\text { specifications above the ministerial level }\end{array}$ & 4 & 11 \\
\hline $\begin{array}{l}\text { Number of papers published above } \\
\text { provincial and ministerial level }\end{array}$ & 195 & 680 \\
\hline $\begin{array}{l}\text { Investment in science and technology } \\
\text { research and direction (10000 yuan) }\end{array}$ & 4 & \multirow{2}{*}{6} \\
\hline
\end{tabular}




\section{Conclusion and prospect}

This paper is a research and exploration on the application of total risk management theory in Chinese construction enterprises. In the immature stage of the formation of risk management theory, through the response to the application of a state-owned enterprise's overall risk management theory, the formulation, risk identification, risk control and risk strategy of risk strategies as well as the comprehensive improvement of the enterprise's internal control system, risk control ability, market share and other aspects after the implementing of overall risk management, it verifies the effectiveness of overall risk management theory in Chinese construction enterprises. In particular, it makes a more in-depth analysis on the identification and control of risk and the improvement of enterprise internal control system. According to the analysis and research results, the following conclusions are drawn:

(1) By summarizing and refining the risk management theory of construction enterprises and deeply analyzing various potential risks faced by construction enterprises, it can be concluded that for the enterprises that have established enterprise risk management system, they will have greater competitive advantage in the face of loss accidents, and the integrated comprehensive risk management system can fundamentally improve the risk management ability of construction enterprises, enhance the core competitiveness of enterprises in the market, so as to realize the sustainable development of enterprises.

(2) This paper puts forward the methods of risk identification, including historical experience method, expert interview method, analysis tool method, analytic hierarchy process, checklist method, decomposition analysis method and graphic method. Through these methods enterprises can correctly identify and evaluate various risks faced by them, which can provide basic basis for enterprise strategic decision-making;

(3) In project level and enterprise level risk management cases, different risk response strategies such as risk retention, risk transfer, risk control and risk avoidance are formulated for the degree of risk control by using typical risk events, systematic risk database and risk coordinate map, so as to avoid the serious consequences of organizational strategic risk and project level system risk, which has achieved a good situation in which the enterprise development is sustained, healthy and stable, the market share is continuously improved, and the project life cycle is fully controlled in terms of construction period, quality, safety and cost. The research results provide reference and basis for maintaining the vitality of the construction market.

(4) Through the analysis of empirical cases, it is proved that connecting risk preference with enterprise strategy can ensure that the risk management strategy is consistent with the development strategy of the organization and the value of shareholders. At the same time, it provides tools for identifying and evaluating risks, which is conducive to identifying and evaluating the risks faced by the organization.

To sum up, there is a big gap between China and foreign countries in terms of theory and practice in the research of comprehensive risk management of construction enterprises. The main manifestations are:

(1) The research on the risk of construction enterprises mainly focuses on the project level risk management.

(2) Lack of understanding of ERM's position in enterprise development, without management and control rise to the strategic level.

(3) ERM cannot be highly integrated with enterprise management, and its operability is not strong in the process of system formulation.

(4) The construction of risk management organization is not perfect, there is no separate risk management department, and there is no soul department to promote strongly.

(5) A good risk management culture has not been formed and cultivated, and senior management and 
employees lack risk management awareness.

In view of these five problems, the application of comprehensive risk management in construction enterprises has a long way to go, especially the scientificity, systematicness and operability of risk identification technology need further research and discussion.

\section{Disclosure statement}

The author declares no conflict of interest.

\section{References}

[1] Xie C, 2012, Discussion on Project Management Risk and Its Prevention in Construction Enterprises. Contemporary Economics, 2021(8): 20-21.

[2] Zeng X, 2011, Analysis on Risk Management of Highway Bridge Construction. Theoretical Research in Urban Construction (Electronic Version), (29).

[3] Wu H, 2009, Application of Monte Carlo Method Considering Variable Correlation in Construction Risk Management. Beijing University of Technology.

[4] Zhang W, Hu Q, Zhang A, 2007, Research on Comprehensive Risk Management of Electric Power Enterprises. Electric Power Technologic Economics, 02:61-65.

[5] Huang H, Ning Z, 2008, Research on Dynamic Risk Control of Shanghai Rail Transit Construction. Proceedings of 2008 Cross-Straits Rail Transit Construction and Environmental Engineering Advanced Technology Forum. 167-171.

[6] Reza A, Azari K, Mousavi N, et al., 2011, Risk Assessment Model Selection in Construction Industry. Expert Systems with Application, 38(8): 9105-9111.

[7] Lei S, 2002, International Engineering Risk Management and Insurance. Communication and space. China Architecture Publishing. 